Volume 8, No.1.3, 2019

International Journal of Advanced Trends in Computer Science and Engineering

Available Online at http://www.warse.org/IJATCSE/static/pdf/file/ijatcse1981.32019.pdf

https://doi.org/10.30534/ijatcse/2019/1981.32019

\title{
Exergy and Regression Analysis for Optimization of Electric Chillers at a Gas District Cooling Plant
}

\author{
Zainal A. Abdul Karim¹, M. Afiq Sidqi², M. Amin A. Majid ${ }^{3}$, Masdi Muhammad ${ }^{4}$, Hidetaka Aoki ${ }^{5}$, and \\ Zhang Xiaoming ${ }^{6}$ \\ ${ }^{1}$ Department of Mechanical Engineering, Universiti Teknologi PETRONAS, 32610 Seri Iskandar, Perak, \\ Malaysia, ambri@utp.edu.my. \\ ${ }^{2}$ Research and Development Centre, Hitachi Asia (Malaysia) Sdn. Bhd. \\ ${ }^{3}$ Research and Development Centre, Hitachi Asia Ltd.
}

\begin{abstract}
At present, most plant engineers experience uncertainty on the optimal performance of electric chillers (ECs) even after repairs or maintenance services. This is evidence to a district cooling plant, where the current performance of ECs are not consistent and optimized causing energy losses and low efficiency of the equipment. Thus, an analytical model of the ECs under steady state plant operating condition is needed in order to achieve better optimization and to improve equipment efficiency. To increase the exergy efficiency and coefficient of performance of ECs, an exergy-based analytical model was developed by implementing ANOVA and regression analysis on significant parameters. The findings showed that for the exergy efficiency, the actual efficiency is lower due to insufficient chilled water flowrate and low chilled water return temperature. The EC efficiency can be optimized at COP of 3.1 when the cooling load is $311.41 \mathrm{RT} / \mathrm{h}$ for an electric consumption of $353.28 \mathrm{~kW} / \mathrm{h}$. Hence, this paper exhibit the ability of the exergy-based analytical model to accurately predict the actual performance of the equipment and provide optimizing strategies can be implemented by the plant.
\end{abstract}

Key words : Exergy, Electric Chiller, Linear Regression, Optimization.

\section{INTRODUCTION}

The combination of the first law and second law of thermodynamics are significant in analyzing energy conversion process of the refrigeration system. The major source of irreversibility in the vapour compression refrigeration cycle is due to the heat transfer between the ambient air and the refrigeration system which takes place at a fixed temperature difference. In consequence, the irreversibility will cause the degradation of the refrigeration system performance.

The efficiency of the energy consumed during energy conversion process can be determined based on the concept of exergy and exergy destruction. Esfahani et al. [1] implemented exergy analysis on three power and fresh water cogeneration systems that integrate a gas turbine power plant and a reverse osmosis desalination system. They found that cogeneration system with the absorption chiller can increase exergy and energy efficiency and net power generation.

Regulagadda et al. [2] undertook exergy analysis on a subcritical boiler-turbine generator for a coal-fired power plant. The outcome of this analysis quantified that the boiler and turbine had contributed largest exergy losses in the power plant. Ganjehsarabi et al. [3] employed exergy analysis on geothermal power plant in order to assess plant performance and determine locations of exergy destruction. It was found that, the most efficient equipment was the preheater. Ezan et al. [4] used exergetic analysis in evaluating performance of latent heat storage in both charging and discharging processes. The outcome of this analysis indicated that for charging period, exergy efficiency increased as inlet temperature and flow rate increased. Furthermore, they also found that for discharging period, the temperature difference between the melting temperature of the phase change material and the inlet temperature of the heat transfer fluid had affected the amount of irreversibility.

Exergy analysis offers an instrument for a clear variation between energy losses to the surrounding and internal irreversibility in the process [5]. Rosen et al. [6] applied exergy analysis on coal-fired electrical generating station in variation of dead-state properties. The analysis revealed that exergy values are not significantly sensitive to variation of dead state properties of thermal system. Thus, exergy delivers a more convincing understanding and a convenient instrument for engineering assessment [7].

The exergy analysis was performed on the vapour compression refrigeration cycle by Ahamed et al. [8]. They found that exergy rest on environmental temperature, evaporating temperature, condensing temperature sub-cooling and compressor pressure. The foremost contribution toward exergy losses happened in the vapour compression system was due to compressor components. Previously, Amear et al. [9] had evaluated the performance of ECs based on the coefficient of performance $(C O P)$. This $C O P$ method of analysis was unable to explain the maximum amount of 
energy utilization by ECs. UTP GDC implementing cogeneration system which involves electric chillers (ECs) as one of the chilled water generating facilities at the gas district cooling plant. However, the current performance of ECs are not consistent causing energy losses and low efficiency of the equipment.

The main objective of the present research is to develop the exergy-based analytical model of ECs under steady state of plant operating condition and to produce exergy efficiency optimization line, electricity consumption optimization line and cooling capacity optimization line for ECs optimization. The empirical equations for the energy and exergy efficiency were derived by regression analysis. This developed equation was validated with another set of ECs operation data. The effect of significant parameters including ambient temperature $\left(T_{o}\right)$, volume flowrate $(\dot{V})$, chilled water return temperature $\left(T_{c h w r}\right)$, chilled water supplied temperature $\left(T_{\text {chws }}\right)$, electricity consumption $\left(E_{c h}\right)$ and cooling capacity $\left(Q_{c l}\right)$ toward exergy efficiency $\left(\eta_{e x}\right)$ were

\section{EXERGY ANALYSIS}

The 4 units of air-cooled electric chiller (EC) system for the current study operate on the vapour compression refrigeration cycle as shown in Figure 1. The electric motor supply work into the system via the compressor unit. After that, the refrigerant is compressed isentropically at the compressor stage (1). The heat due to the compression of the refrigerant vapour by the compressor $\left(Q_{H}\right)$ is rejected to the surrounding at the condenser stage (2). Then, at the expansion valve stage (3), the refrigerant is expanded isentropically. The heat from the chilled water return $\left(Q_{L}\right)$ is absorbed by the refrigerant at the evaporator stage (4). The heat from chilled water return is removed by the refrigerant inside the evaporator. As a consequence of that, the liquid-vapour state of refrigerant change into vapour state. Then, the chilled water supplied is channelled to the campus through the heat exchanger (5).

The exergy efficiency of the system is determined based on the Second Law of Thermodynamic analysis. For the exergy analysis, the following assumptions are made. All streams of vapour compression refrigeration system are at steady state condition. There is no pressure loss occurred in the pipeline. Kinetic energy and potential energy are not considered for the analysis. The refrigerant temperature in the evaporator is equal to the chilled water supplied temperature $\left(T_{c h w s}\right)$.

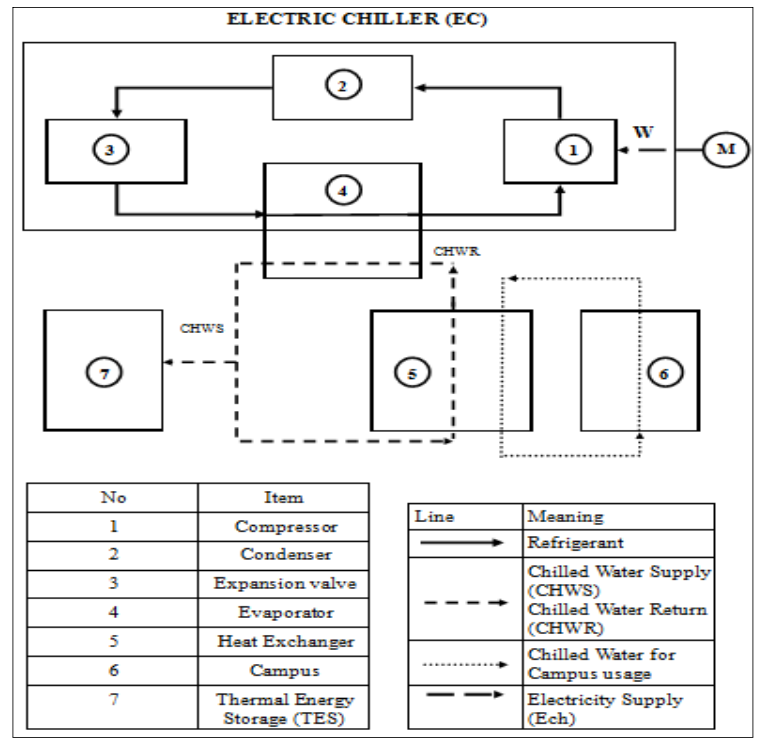

Figure 1: Schematic diagram of ECs chilled water system.

Figure 2 describes the Carnot refrigeration cycle for ECs. The heat source is generated at the evaporator side. Most of the heat that come from heat source will be channelled to the condenser site. Then, the condenser will reject the heat into the surrounding air.

The operating data of EC-B, EC-C and EC-D were collected through the plant data acquisition system. EC-A was not in operation during the data acquisition period, hence the operation of EC-A was omitted. A 28-days period of the chiller operation data were considered for the analysis. The initial and final date of the chiller operation data were November 8, 2015 and December 5, 2015 respectively.

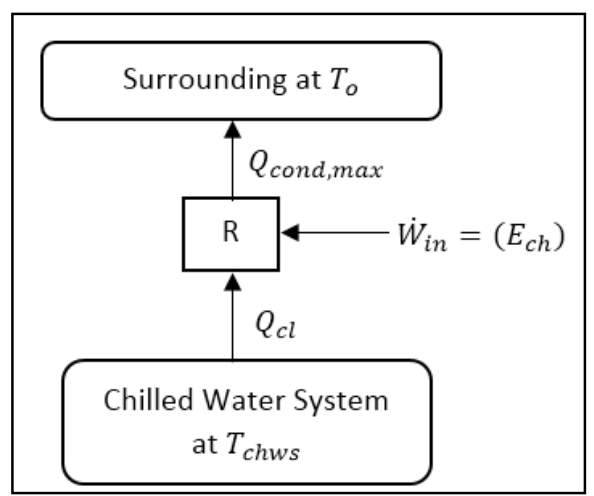

Figure 2: Refrigeration Cycle of ECs.

Based on the daily plant data, the cooling capacity $\left(Q_{c l}\right)$, electricity consumption $\left(E_{c h}\right)$ and coefficient of performance $(C O P)$ of EC-B, EC-C and EC-D were computed. The relation between $Q_{c l}$ to the chilled water system is given by Equation (1) as follows,

$\dot{Q}_{c l}=\rho \dot{V} C_{p}\left(T_{c h w r}-T_{c h w s}\right)$

where, density of water $\left(\rho=999.8 \mathrm{~kg} / \mathrm{m}^{3}\right)$, volume flowrate ( $\dot{V})$, specific heat capacity of chilled water $\left(C_{p}=4.192\right.$ 
$\mathrm{kJ} / \mathrm{kg} \cdot \mathrm{K})$, chilled water return temperature $\left(T_{c h w r}\right)$ and chilled water supplied temperature $\left(T_{\text {chws }}\right)$. COP of the EC is found from Equation (2),

$C O P=\frac{Q_{c l}}{E_{c h}}$

The quantification of the ideal reversible work produced by EC is represented by Equation (3), where thermal efficiency of the Carnot cycle $\left(\eta_{t h, r e v}\right)$ is expressed in term of ambient temperature $\left(T_{o}\right)$ and chilled water supplied temperature $\left(T_{\text {chws }}\right)$.

$\eta_{\text {th,rev }}=\left[1-\frac{T_{o}}{T_{\text {chws }}}\right]$

Equation (4) is used to determine the maximum reversible amount of heat into the condenser $\left(Q_{\text {cond,max }}\right)$,

$Q_{\text {cond }, \max }=\left[1-\frac{T_{o}}{T_{\text {chws }}}\right] Q_{c l}$

The exergy efficiency $\left(\eta_{e x}\right)$ of a EC correlates with the maximum reversible amount of heat into the condenser $\left(Q_{\text {cond,max }}\right)$ and the electricity consumption of the chiller which is the pure exergy $\left(E_{c h}=E_{e x, c h}\right)$, is given by Equation (5) as;

$\eta_{e x}=\frac{Q_{\text {cond, } \max }}{E_{c h}}$

$\eta_{e x}$ can be associated to the chiller $C O P$ by Equation (6).

$\eta_{e x}=\left[1-\frac{T_{o}}{T_{\text {chws }}}\right] C O P$

\section{EXERGY-BASED ANALYTICAL MODEL}

The following paragraphs describe the development of the exergy based analytical model to determine the electricity consumptions of the electric chillers.

\subsection{Analytical Model of Electric Chillers}

ANOVA was performed to study the relative significance of the process variables toward the response on electricity consumption $\left(E_{c h}\right)$.

Table 1 shows the computed results of the ANOVA with 95\% confidence. The F-value quantified that all listed parameters of volume flowrate $(\dot{V})$, chilled water return temperature $\left(T_{\text {chwr }}\right)$, chilled water supplied temperature $\left(T_{\text {chws }}\right)$ and coefficient of performance $(C O P)$ have significant effect on the $\left(E_{c h}\right)$. Moreover, very low probability value (P-value) confirmed the model is statistical significant. The regression Equation (7) was found to have $R^{2}$ and adjusted $R^{2}$ values of 0.9647 and 0.9645 respectively, showing a good fit and thus confirming the linear relationship of the response, $\left(E_{c h}\right)$ and the inputs, $\dot{V}, T_{\text {chwr }}, T_{\text {chws }}$, and $C O P$.

Table 1: Analysis of Variance (ANOVA) for Electricity Consumption $\left(E_{c h}\right)$.

\begin{tabular}{|c|c|c|c|c|c|c|}
\hline \multicolumn{7}{|c|}{ Analysis of Variance } \\
\hline \multicolumn{2}{|l|}{ Source } & Adj SS & Adj MS & \multicolumn{2}{|c|}{ F-Value } & P-Value \\
\hline Regression & 4 & 3189693 & 797423 & \multicolumn{2}{|c|}{8965.07} & 0.000 \\
\hline Flowrate_m3 & 1 & 45877 & 45877 & \multicolumn{2}{|c|}{515.77} & 0.000 \\
\hline T.chw & 1 & 2150741 & 2150741 & \multicolumn{2}{|c|}{24179.80} & 0.000 \\
\hline T.chws & 1 & 761170 & 761170 & \multicolumn{2}{|c|}{8557.48} & 0.000 \\
\hline COP & 1 & 1135429 & \multirow{2}{*}{$\begin{array}{l}1135429 \\
89\end{array}$} & \multicolumn{2}{|c|}{12765.11} & 0.000 \\
\hline Error & & 116877 & & & & \\
\hline Total & 1318 & 3306570 & & & & \\
\hline \multicolumn{7}{|c|}{ Model Summary } \\
\hline $\begin{array}{c}S \\
9.43122\end{array}$ & $\underset{96.47 \%}{\text { R-sq }}$ & $\begin{array}{l}\text { R-sq(adj) } \\
96.45 \%\end{array}$ & $\begin{array}{c}\text { R-sq(pred) } \\
\mathbf{9 6 . 3 4 \%}\end{array}$ & & & \\
\hline \multicolumn{7}{|l|}{ Coefficients } \\
\hline Term & Coef & SE Coef & T-Value & P-Value & VIF & \\
\hline Constant & 110.85 & 5.58 & 19.87 & 0.000 & & \\
\hline Flowrate_m3 & 0.7122 & 0.0314 & 22.71 & 0.000 & 1.83 & \\
\hline T.chwr & 45.100 & 0.290 & 155.50 & 0.000 & 2.29 & \\
\hline T.chws & -40.042 & 0.433 & -92.51 & 0.000 & 2.86 & \\
\hline COP & -69.164 & 0.612 & -112.98 & 0.000 & 1.37 & \\
\hline
\end{tabular}

$$
E_{c h}=110.85+0.7122(\dot{V})+45.1\left(T_{c h w r}\right)-40.042\left(T_{c h w s}\right)-69.164(C O P)
$$

For the exergy efficiency, equation (8) demonstrates that equation (6) can be associated to both equations (1) and (7) in order to form an exergy-based analytical model.

$\eta_{\text {ex }}=\left[1-\frac{T_{o}}{T_{\text {chws }}}\right] \cdot\left[\frac{\rho \dot{V} C_{p}\left(T_{c h w r}-T_{\text {chws }}\right)}{110.85+0.7122(\dot{V})+45.1\left(T_{c h w r}\right)-40.042\left(T_{\text {chws }}\right)-69.164(C O P)}\right]$

\subsection{Model Validation}

The validation of electricity consumption $\left(E_{c h}\right)$, Equation (7), is displayed in Figure 3 which exhibits $E_{c h}$ of EC-B, EC-C and EC-D over a period of 3 days, which started on December 6, 2015 and ended on December 8, 2015. The $E_{c h}$ calculated line and $E_{c h}$ actual defined the value of calculated $E_{c h}$ per hour and the value of actual $E_{c h}$ per hour for ECs respectively.

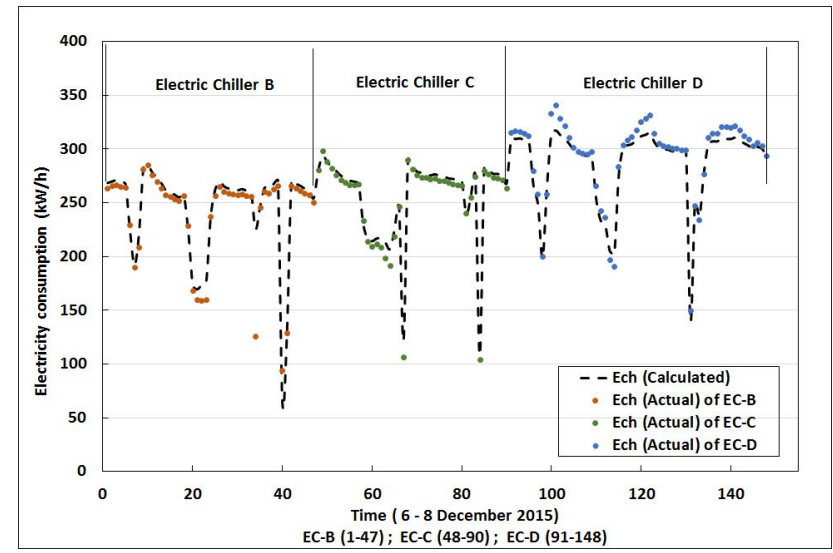

Figure 3: ECs $E_{c h}$ (Actual), $E_{c h}$ (Calculated) vs Time (December 6 - 8, 2015). 


\section{OPTIMIZATION OF ELECTRIC CHILLER}

The following paragraphs describe the potential optimization strategies for exergy efficiency, ECs electric consumption and cooling capacity.

\subsection{Exergy efficiency versus coefficient of performance}

The optimization of the ECs exergy efficiency $\left(\eta_{e x}\right)$ by manipulating values of ambient temperature $\left(T_{o}\right)$ at fixed volume flow rate $\left(\dot{V}=131 \mathrm{~m}^{3} / \mathrm{h}\right)$, chilled water return temperature $\left(T_{\text {chwr }}=12.5^{\circ} \mathrm{C}\right)$, chilled water supplied temperature $\left(T_{\text {chws }}=5^{\circ} \mathrm{C}\right)$ and $C O P$ are shown in Figure 4. The figure depicts $\eta_{e x}$ of EC-B, EC-C and EC-D over a period of 24 hours, which started on November 9. The $\eta_{e x}$ (optimized) lines defined the value of optimized $\eta_{e x}$ per hour based on different $T_{o}$ which are $27.2^{\circ} \mathrm{C}, 29.2^{\circ} \mathrm{C}$ and $31.2^{\circ} \mathrm{C}$. The $C O P$ (design specification) shown as dashes line exhibits the value of ECs $C O P$ based on its design specification $(C O P=3.14)$. Meanwhile, the exergy (actual) dotted marks are referring to the actual amount of exergy efficiency reached by each ECs. The figure shows the actual value of ECs exergy efficiency is directly proportional to the value of ECs COP. In addition, the actual value of ECs exergy efficiency slightly drop below the exergy efficiency optimized lines due to insufficient amount of significant parameters such as volume flowrate of the water $(\dot{V})<131 \mathrm{~m}^{3} / \mathrm{h}$ and chilled water return temperature $\left(T_{c h w r}\right)<$ $12.5^{\circ} \mathrm{C}$. The chilled water supplied temperature $\left(T_{\text {chws }}\right)>$ $5.0^{\circ} \mathrm{C}$ also causes degradation of ECs exergy efficiency. The ECs design specification $C O P$ is surpassed by the actual ECs COP. This scenario happened due to high ambient temperature $\left(T_{o}\right)>\approx 27.2^{\circ} \mathrm{C}$.

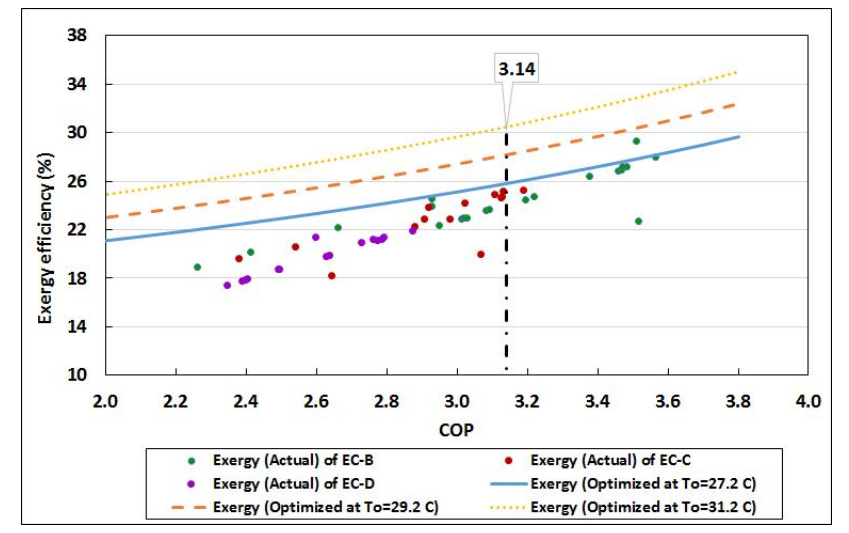

Figure 4: Exergy optimization potential at varying COP of ECs.

\subsection{Electricity consumption and cooling capacity versus coefficient of performance}

The optimization of the ECs electricity consumption $\left(E_{c h}\right)$ and cooling capacity $\left(Q_{c l}\right)$ was investigated by manipulating value of volume flowrate $\left(\dot{V}=131 \mathrm{~m}^{3} / \mathrm{h}\right)$, chilled water return temperature $\left.\left(T_{c h w r}\right)=12.5^{\circ} \mathrm{C}\right)$, chilled water supplied temperature $\left(T_{c h w s}=5^{\circ} \mathrm{C}\right)$ and COP are showed in Figure 5

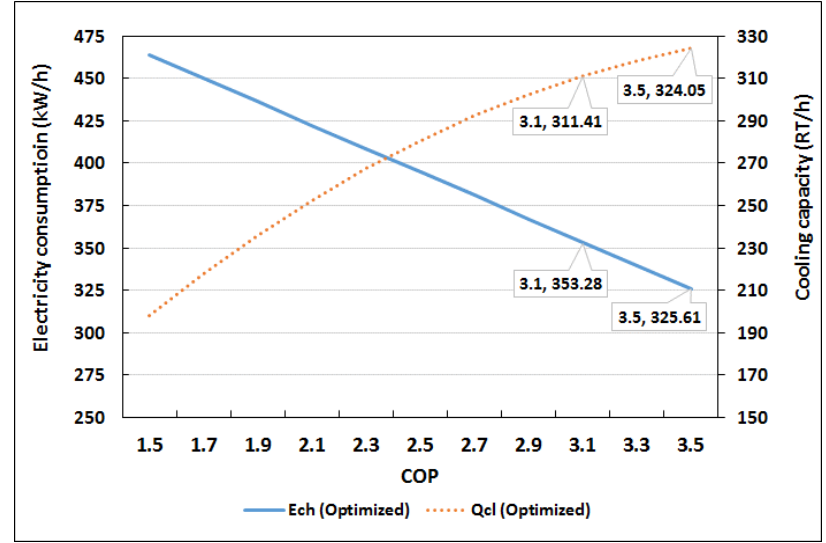

Figure 5: Electricity consumption (optimized) and cooling capacity (optimized) under varying $\mathrm{COP}=1.5$ to 3.5 .

The $E_{c h}$ (optimized) line and $Q_{c l}$ (optimized) line defined the value of optimized $E_{c h}$ per hour and value of optimized $Q_{c l}$ per hour based on varying $C O P$ respectively. The graph shows the amount of optimized value of $E_{c h}$ and $Q_{c l}$ at $C O P=3.1$ are $353.28 \mathrm{~kW} / \mathrm{h}$ and $311.41 \mathrm{RT} / \mathrm{h}$ respectively. Furthermore, the optimized value of $E_{c h}$ and $Q_{c l}$ at $C O P=3.5$ are $325.61 \mathrm{~kW} / \mathrm{h}$ and $324.05 \mathrm{RT} / \mathrm{h}$ respectively.

\subsection{Cooling capacity versus chilled water return temperature}

The optimization of the ECs $Q_{c l}$ by manipulating value of volume flowrate $\left(\dot{V}=131 \mathrm{~m}^{3} / \mathrm{h}\right)$ chilled water supplied temperature $\left(T_{c h w r}=5^{\circ} \mathrm{C}\right)$ and chilled water return temperature $\left(T_{c h w r}\right)$ is showed in Figure 6. The graph displays $Q_{c l}$ of ECs over a period of 24 hours, which started on November 9 . The $Q_{c l}$ (optimized) line defined the value of optimized $Q_{c l}$ per hour. The $Q_{c l}$ (max design capacity) dashes line is included to indicate the maximum reachable amount of cooling capacity $\left(Q_{c l}=325 \mathrm{RT} / \mathrm{h}\right)$ per hour for ECs. Furthermore, the $T_{c h w r}$ (design specification) dashes line exhibits the value of ECs chilled water return temperature $\left(T_{c h w r}=12.5^{\circ} \mathrm{C}\right)$ based on its design specification. The $Q_{c l}$ (actual) shown as dotted marks refers to the actual amount of cooling capacity reached by ECs.

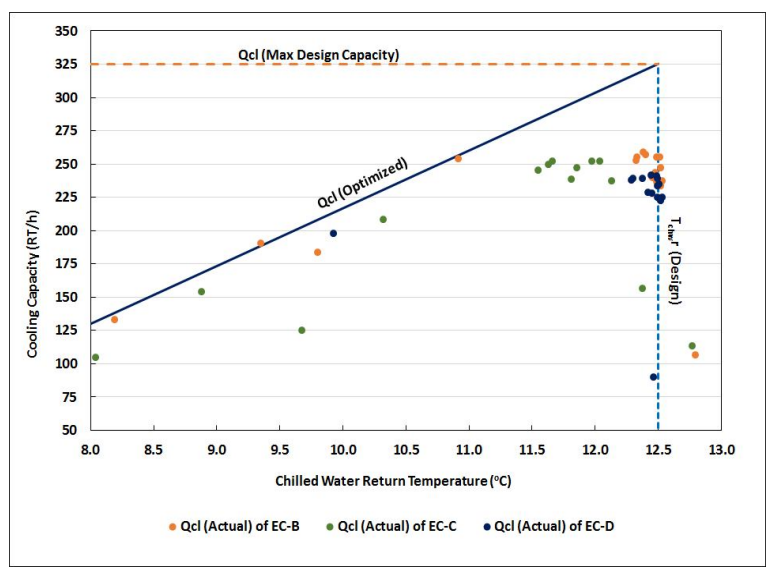

Figure 6: $Q_{c l}$ (optimized) under varying $T_{c h w r}=8^{\circ} \mathrm{C}$ until $T_{c h w r}$ $=12.5^{\circ} \mathrm{C}$ 
The graph displays the actual value of ECs cooling capacity directly proportional to the value of ECs $T_{c h w r}$ Besides, the actual value of ECs cooling capacity slightly drop below the cooling capacity optimized line due to insufficient amount of volume flowrate of the water $\dot{V}=131 \mathrm{~m}^{3} / \mathrm{h}$. In addition, the chilled water supplied temperature $\left(T_{\text {chwr }}\right)>5.0^{\circ} \mathrm{C}$ also causes reduction of ECs cooling capacity. Several values of the actual cooling capacity for ECs are placed beyond the design specification chilled water return temperature $\left(T_{c h w r}\right)$, occurred due to the instability of ECs during startup.

\section{CONCLUSION}

The findings showed that the actual value of electric chiller exergy efficiency is directly proportional to $C O P$. In addition, the model was able to indicate that the actual exergy efficiency and cooling capacity of the chillers were below the optimized values and this was due low flowrate of chilled water low chilled water return temperature. It was also observed that the optimized cooling capacity at COP of 3.1 is at $311.41 \mathrm{RT} / \mathrm{h}$ for the best electrical consumption of 353.28 $\mathrm{kW} / \mathrm{h}$. Other exergetic optimization can also be found at various $C O P$ using the model.

\section{ACKNOWLEDGEMENT}

The author would like to acknowledge Universiti Teknologi Petronas (UTP) for the Graduate Local Assistantship (GLA) scheme, and Hitachi Ltd. for the grant in funding the project.

\section{REFERENCES}

1. I. J. Esfahani and C. Yoo (2013), Exergy analysis and parametric optimization of three power and fresh water cogeneration systems using refrigeration chillers. Energy 59, 340-355. https://doi.org/10.1016/j.energy.2013.07.040

2. P. Regulagadda, I. Dincer, and G. Naterer (2010), Exergy analysis of a thermal power plant with measured boiler and turbine losses. Applied Thermal Engineering 30, 970-976. https://doi.org/10.1016/j.applthermaleng.2010.01.008

3. H. Ganjehsarabi, A. Gungor, and I. Dincer (2012), Exergetic performance analysis of Dora II geothermal power plant in Turkey. Energy 46, 101-108. https://doi.org/10.1016/j.energy.2012.02.039

4. M. A. Ezan, M. Ozdogan, H. Gunerhan, A. Erek, and A. Hepbasli (2010), Energetic and exergetic analysis and assessment of a thermal energy storage (TES) unit for building applications. Energy and Buildings 42, 1896-1901.

https://doi.org/10.1016/j.enbuild.2010.05.025

5. M. Kopac and A. Hilalci (2007), Effect of ambient temperature on the efficiency of the regenerative and reheat Çatalağzı power plant in Turkey. Applied Thermal Engineering 27, 1377-1385. https://doi.org/10.1016/j.applthermaleng.2006.10.029

6. M. A. Rosen and I. Dincer (2004), Effect of varying dead-state properties on energy and exergy analyses of thermal systems. International Journal of Thermal Sciences 43, 121-133.

https://doi.org/10.1016/j.ijthermalsci.2003.05.004

7. Z. Utlu and A. Hepbasli (2007), A review on analyzing and evaluating the energy utilization efficiency of countries. Renewable and Sustainable Energy Reviews 11, 1-29. https://doi.org/10.1016/j.rser.2004.12.005

8. J. Ahamed, R. Saidur, and H. Masjuki (2011), A review on exergy analysis of vapor compression refrigeration system. Renewable and Sustainable Energy Reviews 15, 1593-1600. https://doi.org/10.1016/j.rser.2010.11.039

9. S. Amear, S. Ariffin, A. Nordin, N. Buyamin, M. Amin, and A. Majid (2013), Performance analysis of absorption and electric chillers at a gas district cooling plant. Asian Journal of Scientific Research 6, 299. https://doi.org/10.3923/ajsr.2013.299.306 